\title{
PRAKTEK PENGELOLAAN PRODUKSI DAN KONSUMSI YANG BERKELANJUTAN PADA MASYARAKAT ADAT PESISIR MOI KELIM DI KAMPUNG MALAUMKARTA KABUPATEN SORONG PAPUA BARAT
}

\author{
Sustainable Production Management and Consumption of \\ Indigenous Coastal Community Moi Kelim at Malaumkarta \\ Village, Sorong District, West Papua
}

\author{
Zuzy Anna \\ Fakultas Perikanan dan IImu Kelautan Universitas Padjadjaran \\ SDGS Center Universitas Padjadjaran \\ JI.Dipatiukur No.46, Lebakgede, Coblong, Kota Bandung, Jawa Barat, Indonesia \\ *email: z.anna@unpad.ac.id
}

Diterima tanggal: 3 Januari 2018 Diterima setelah perbaikan: 9 Maret 2018

Disetujui terbit: 7 Juni 2018

\begin{abstract}
ABSTRAK
Masyarakat adat pesisir dipercaya memiliki kemampuan pengetahuan dan kearifan tradisional dalam pengelolaan produksi dan konsumsi sumber daya alam dan jasa lingkungan yang berkelanjutan. Sayangnya, masyarakat adat sekarang ini masih dianggap sebagai penghalang bagi pembangunan skala besar di kawasan pesisir. Akibatnya, konflik sering terjadi manakala kegiatan pembangunan dilakukan di kawasan ini. Pada akhirnya masyarakat adat seringkali dikorbankan demi untuk pembangunan, karena dianggap tidak memiliki manfaat lebih baik dibandingkan dengan nilai ekonomi yang diperoleh dari pembangunan. Salah satu penyebab adalah pemahaman para pengambil keputusan mengenai kemampuan masyarakat adat dalam mengelola secara berkelanjutan kawasan ini masih belum banyak. Penelitian ini membahas bagaimana praktek pengelolaan produksi dan konsumsi yang berkelanjutan dapat dijadikan sebagai argument untuk menempatkan masyarakat adat dalam posisi sejajar melalui pembangunan yang inklusif, adil dan berkelanjutan. Penelitian ini dilakukan pada masyarakat adat Moi Kelim di Kampung Malaumkarta, Kabupaten Sorong dengan metode survey lapang dan wawancara, serta Focus Group Discussion (FGD). Hasil penelitian menunjukkan kemampuan pengetahuan dan kearifan tradisional masyarakat pesisir yang mampu menghasilkan ketahanan pangan dan nilai ekonomi dari kegiatan produksi dan konsumsi yang berkelanjutan, seperti sasi, pengelolaan hutan dan lain-lain.
\end{abstract}

Kata Kunci: masyarakat adat pesisir; pengetahuan dan kearifan tradisional; konflik; pembangunan inklusif; produksi dan konsumsi yang berkelanjutan; sasi

\begin{abstract}
Indigenous coastal community is believed to have traditional knowledge and wisdom in sustainable production management and resources consumption. On the contrary, they are considered a barrier to a large scale development in the coastal area, and it leads to conflict whenever government develop this area. In consequence, indigenous people are often to be sacrificed since they are considered to have less benefit compared to economic value of the development. This is due to policy makers' perception that they have inadequate capacity to manage a sustainable territory. The study describes how production management and sustainable consumption could involve indigenous people on the same level through inclusive development. This study was conducted towards Moi Kelim community at Malaumkarta Village, Sorong Distric through field survey, interviews and focus group discussion. The findings further revealed how coastal community could deliver their traditional knowledge and wisdom into food security and economic value of sustainable production and consumption such as sasi, forest management, etc.
\end{abstract}

Keywords: coastal indigenous peoples; traditional knowledge and wisdom; conflict; inclusive development; sustainable production and consumption; sasi 


\section{PENDAHULUAN}

Pesisir adalah salah satu kawasan bumi yang memiliki kekayaan sumber daya alam berlimpah baik dari daratannya maupun dari perairan pesisir dan lautnya (Crossland et al., 2005). Selain itu kawasan ini juga memiliki kekayaan jasa lingkungan yang sangat luar biasa dalam bentuk pemandangan alam yang indah dan berbagai jasa lingkungan lainnya. Tidak mengherankan jika hampir $60 \%$ kota-kota besar di dunia berada di kawasan pesisir, dan hampir $40 \%$ dari penduduk dunia berada pada wilayah $100 \mathrm{~km}$ dari pesisir (Nicholls et al., 2007). Beberapa wilayah pesisir yang berada di daerahdaerah terpencilpun sekarang ini tidak luput dari perhatian, apalagi daerah terpencil yang dianggap memiliki potensi sumber daya alam dan jasa lingkungan yang berlimpah. Pembangunan pariwisata misalnya mulai membidik kawasankawasan pesisir yang berada pada wilayah yang masih belum terjamah, karena dianggap mampu memberikan nilai ekonomi yang tinggi, dalam kondisi masyarakat dunia yang mulai membaik perekonomiannya, dan mengejar kebutuhan tertier dalam bentuk rekreasi.

Kawasan pesisir yang terpencil seperti di kawasan Indonesia timur pada umumnya masih dihuni oleh masyarakat adat yang telah mendiami wilayah tersebut ber abad lalu. Masyarakat adat pesisir adalah masyarakat yang dapat mencakup kelompok penduduk asli yang diakui dan tidak diakui, dan/atau minoritas yang berasal dari suatu daerah pesisir. Definisi masyarakat adat yang paling umum digunakan dan dikembangkan oleh Perserikatan BangsaBangsa (Cobo, 1983; Welker, 2016; ILO 2018) adalah mencirikan komunitas, masyarakat, dan bangsa Pribumi, sebagai "memiliki kesinambungan historis dengan masyarakat pra-invasi dan pra-kolonial yang berkembang di wilayah mereka dan menganggap diri mereka berbeda dari sektor lain. Mereka membentuk sektor-sektor non-dominan, dan bertekad untuk melestarikan, mengembangkan dan mengirimkan kepada generasi masa depan wilayah leluhur mereka, dan identitas etnis mereka, sebagai dasar dari kelangsungan eksistensi mereka sebagai masyarakat.
Wittman (2011) mengatakan bahwa masyarakat adat pesisir memiliki keterikatan dengan ekosistem pesisir dan laut secara langsung dan tidak langsung, yang selain menjadi tumpuan ketahanan pangan mereka, juga melestarikan warisan budaya mereka. Di sisi lain hal ini menyebabkan masyarakat adat pesisir menjadi sangat rentan terhadap kondisi ekologis dan juga sumber daya alam dan jasa lingkungan yang ada, seperti misalnya perubahan iklim dan deplesi sumber daya ikan dan sumber daya pesisir dan laut lainnya (Pauli, 1998; Jackson, 2001; Cheung et al., 2013). Cisneros et al. (2016), menyatakan bahwa masyarakat adat pesisir sangat rentan terhadap perubahan ekosistem dan ekonomi, hal ini telah diketahui pada level lokal dan regional. Perubahan pola pemanfaatan sumber daya pesisir dan laut di wilayah mereka akan berdampak secara signifikan bagi perilaku produksi dan konsumsi mereka.

Masyarakat adat pesisir dikenal memiliki kemampuan untuk mengelola dan mengkonservasi sumber daya alam pesisir dan lingkungannya secara berkelanjutan. Pola produksi dan konsumsi mereka yang cenderung bersifat subsisten, serta pengetahuan dan kearifan lokal yang mereka miliki selama berabad-abad atau melalui transformasi budaya, menjadi salah satu instrumen yang banyak digunakan untuk mempertahankan kesinambungan ketahanan pangan dan ekonomi mereka. Sehingga dengan demikian mereka mampu bertahan dan bahkan mempertahankan kelestarian dan juga biodiversitas sumber daya alam pesisir.

Wilayah pesisir yang kaya akan sumber daya alam dan jasa lingkungan menjadi sangat menarik untuk dikembangkan sebagai kawasan pariwisata misalnya. Hal ini yang banyak terjadi di kawasan pesisir Indonesia timur, dimana kawasan ini masih banyak didiami masyarakat adat. Tekanan ekonomi yang tinggi menyebabkan konflik yang berkepanjangan antara mempertahankan lanscape masyarakat adat pesisir dengan pengembangan kawasan untuk tujuan ekonomi. Berbagai cara dilakukan untuk mempertahankan wilayah adat masyarakat pesisir, diantaranya dengan mendorong 
Undang-Undang, Peraturan Daerah/Peraturan Bupati untuk perlindungan dan pengakuan masyarakat adat, dengan tujuan mereka tidak akan terpinggirkan dana proses pembangunan, dan seyogyanya menjadi bagian integral dalam pembangunan. Faktanya, masyarakat adat pesisir ini seringkali terpinggirkan dan kalah bersaing dengan pilihan pembangunan yang dianggap akan memberikan nilai ekonomi lebih tinggi dibandingkan mempertahankan kawasan masyarakat adat. Berbagai kemungkinan mengapa hal ini dapat terjadi adalah karena sampai saat ini studi yang terkait pemanfaatan sumber daya alam dan jasa lingkungan serta sistem produksi dan konsumsi masyarakat adat pesisir masih sangat jarang dilakukan, karena kurang menarik untuk diteliti kaitan kondisi lokasi yang sangat terpencil (McNiven, 2004; Zeller et al., 2011; Morley, 2015; Davy et al., 2016). Bahkan beberapa riset yang ada menyangkut masyarakat adat dikritik sebagai bias dan mengurangi semangat melindungi mereka (Henry et al., 2004; Davey \& Day, 2008; Kidman, 2007; Sherwood, 2010).

Penelitian ini bertujuan untuk mempelajari pola konsumsi dan produksi masyarakat adat pesisir di Indonesia timur, khususnya masyarakat adat Moi Kelim di Kampung Malaumkarta, kabupaten Sorong, Papua Barat. Pemahaman pola konsumsi dan produksi masyarakat adat pesisir ini sangat penting sebagai bahan masukan dan argumen perlindungan masyarakat adat pesisir yang cenderung termarjinalkan. Penelitian ini menggunakan kerangka metodologis yang mengacu pada penelitian pada skala lokal mikro, sambil membandingkan dengan skala regional. Penelitian juga dilakukan dengan metode survey melalui wawancara dengan kuesioner terstruktur. Selain itu data primer juga diperoleh dari Focus Group Discussion (FGD), sementara data sekunder juga diperoleh dari institusi terkait seperti Pemerintah Kabupaten Sorong dan lembaga masyarakat adat di Kabupaten Sorong.

\section{Masyarakat Adat Pesisir Moi Kelim di Kampung Malaumkarta Kabupaten Sorong}

Masyarakat Moi Kelim tinggal dikawasan pesisir yang masuk dalam wilayah Kampung Malaumkarta di Kabupaten Sorong. Kampung
Malaumkarta, Kabupaten Sorong, Papua Barat. Masyarakat adat Moi Kelim mendiami wilayah yang berdekatan dengan pantai dan juga wilayah pegunungan pedalaman kawasan pesisir. Masyarakat adat Moi Kelim, menempati area di lokasi kecamatan Sorong Timur, Sorong Barat, Sorong Kepulauan, Sorong Utara, Sorong, Sorong Manoi, Klawurum, Malamisimsa, Maladummes Moraid, Makbon, Kalasouw, Kalaili, Sayosa, Kalamono, Mayamuk, Aimas, Mariat, Sorong, Sorong Timur, Sorong Barat, Sorong Kepulauan, Sorong Utara, Sorong Manoi, di Kabupaten Sorong, Provinsi Papua Barat. Namun demikian penduduk terbesar berada di Desa Malaumkarta. Malaumkarta merupakan kampung yang berada di pantai utara Kabupaten Sorong, Papua Barat. Jarak dari desa ini ke Kota Sorong sekitar $48 \mathrm{Km}$ dengan jarak tempuh sekitar 2 jam, menggunakan transportasi umum. Pada awalnya Kampung Malaumkarta dihuni oleh populasi sebanyak 321 orang dengan jumlah rumah sebanyak 85 . Namun demikian, sejalan dengan pemekaran kampung, jumlah penduduk di Kampung Malaumkarta berkurang, karena perpindahan penduduk ke Desa pemekaran, yaitu Suartolo dan kampung Mibi.

Pada saat riset dilakukan (Bulan April 2018), masyarakatadat Moi Kelim di Malaumkarta meliputi jumlah penduduk total sebanyak total 193 orang dengan jumlah kepala keluarga 47. Jumlah laki-laki di kampung Malaumkarta adalah 100 orang sementara perempuan 93 orang. Profesi paling banyak di kampung ini adalah petani merangkap nelayan. Mereka bertani dan menangkap ikan untuk kebutuhan subsisten. Penduduk yang hanya bertani lebih disebabkan karena ketidakmampuan mereka untuk melaut, disabilitas akibat kecelakaan, tua atau sebab lainnya. Responden yang memiliki profesi nelayan dan pernah mendapatkan pelatihan serta memiliki alat tangkap dan juga melakukan kegiatan ekonomi secara komersial, selain subsisten, hanya berjumlah 20 orang.

Kawasan Malaumkarta memiliki keindahan alam dan kekayaan biodiversitas yang sangat luar biasa, meliputi berjenis ikan dan juga burung, serta tumbuhan. Masyarakat adat Moi Kelim dipercaya mengelola dan menjaga keberlanjutan dan keanekaragaman sumber daya alam di 
wilayah ini dengan berbagai pengelolaan yang bersifat pengetahuan dan kearifan tradisional. Sampai saat ini keberlanjutan masih terjaga dengan baik. Namun demikian dengan sangat tingginya tekanan untuk pengembangan wilayah ini menjadi kawasan pariwisata, maka keberlanjutan kawasan ini menjadi terancam. Ditambah lagi dengan semakin berkembangnya konversi lahan hutan di wilayah sekitarnya menjadi perkebunan kelapa sawit.

\section{Praktek Pengelolaan Produksi dan Konsumsi Sumber daya Pesisir Berkelanjutan Masyarakat Adat Moi Kelim}

Masyarakat adat Moi Kelim di kampung Malaumkarta bergantung pada keberadaan sumber daya alam di daratan maupun perairan laut dan sungai. Wilayah daratan adalah lahan yang dikuasai oleh suku Moi Kelim secara turun temurun sebagai ulayat dalam bentuk lahan kebun, hutan dan lokasi pemukiman. Wilayah ini memiliki hutan yang terhampar di wilayah gunung dan perbukitan di sebelah selatan pemukiman, kebun-kebun di pinggiran hutan sampai dengan pemukiman. Wilayah ini juga mencakup ekosistem pesisir berupa pantai pasir, mangrove, muara sungai dan terumbu karang yang ada di bagian utara, meliputi seluruh perairan teluk dan pulau Um.

Praktek pemanfaatan sumber daya alam masyarakat adat Moi Kelim di Malaumkarta lebih kepada model subsisten, yaitu memanfaatkan sumber daya alam hanya untuk kehidupan mereka sehari hari, terutama memenuhi kebutuhan pangan mereka. Keunikan masyarakat adat Moi Kelim adalah tidak adanya dorongan untuk melakukan kegiatan ekonomi komersial, mereka cenderung apatis terhadap kegiatan ekonomi produktif. Masyarakat adat Moi Kelim di Malaumkerta, memperoleh sumber kehidupannya (livelihood) dari sumber daya alam dan jasa lingkungan yang ada di dalam wilayah mereka yang menjadi sumber daya yang bersifat common property (hak kepemilikan bersama) untuk setiap marga yang ada di wilayah tersebut. Sementara hak akses dari sumber daya alam dan jasa lingkungan dapat diperoleh oleh seluruh anggota marga tertentu pada teritori kepemilikan bersama marga tersebut, dan masyarakat yang memiliki keterkaitan misalnya secara perkawinan dalam hal ini disebut sebagai hak makan. Sumber daya hutan, kebun, dan sumber daya perairan pesisir baik perairan dan daratan lainnya menjadi sumber kehidupan masyarakat adat Moi Kelim di Malaumkarta.

Kawasan teresterial di Kampung Malaumkarta dimanfaatkan oleh masyarakat adat Moi Kelim, dengan berbagai praktek pemanfaatan. Kawasan ini digunakan sebagai hutan primer atau hutan konservasi, kawasan pemukiman, kawasan pertanian dan kawasan perkebunan. Masyarakat memanfaatkan lahan di sekitar pemukiman dan juga hutan untuk kegiatan pertanian dan perkebunan. Sumber pangan masyarakat di Malaumkarta berasal dari hutan, kebun dan perairan pesisir. Dari hutan misalnya diperoleh berbagai bahan pangan seperti sagu, babi, rusa, kanguru, berbagai jenis burung. Dari kebun mereka memperoleh berbagai jenis umbiumbian, jagung dan juga buah-buahan, seperti jambu air, jeruk, mangga, pisang, lansat dan lain-lain. Sumber pangan dari perairan pesisir, diantaranya adalah berbagai jenis ikan seperti ikan baronang, ikan kakap merah, kakap hitam, ikan kerapu, dan lain-lain. Selain itu juga ada udang, lobster, Lola, tripang dan lain-lain.

Gambaran model pemanfaatan kawasan teresterial dapat diperoleh dengan menggunakan teknik $F G D$ dan wawancara dengan masyarakat adat setempat. Setiap keluarga masyarakat adat Moi Kelim di Malaumkarta memiliki teritorial kebun yang mereka miliki dan jadikan sebagai sumber penghidupan mereka. Hasil wawancara terhadap 46 Kepala Keluarga (KK) dari rumah tangga yang ada di Malaumkarta, diketahui bahwa hampir setiap rumah tangga penduduk di Malaumkarta paling tidak memiliki dan memanfaatkan secara subsisten beberapa komoditas pertanian seperti sayuran (kangkung, gedi, dan lain-lain), cabai, serta bahan-bahan bumbu lainnya seperti bawang, kemiri, dan lain lain). Masyarakat Malaumkarta menanam, mengambil dari lingkungan sekitar dan memanfaatkan beberapa jenis utama komoditas pangan seperti Sagu, pisang, kelapa, buahbuahan seperti jeruk, mangga, durian, jambu, Matoa. Selain itu masyarakat juga menanam coklat. 
Kebutuhan papan dan energi masyarakat Malaumkarta masih bergantung pada hasil hutan, dalam bentuk kayu, Kayu Buah, Kulit Kayu, bahan atap dari daun sagu. Masyarakat adat Malaumkarta juga memiliki sumber kesehatan dan kecantikan dari hutan, diantaranya daun gatal, buah merah, sarang semut, kulit kayu merbau, Kidimik (tali susu), Kkiwing, Ssentosa, dan lain-lain. Selanjutnya masyarakat adat di Malaumkarta juga mendapatkan sumber pangan dalam hal ini bumbu untuk memasak dari hutan di kawasan kampung ini, misalnya babu (serei), Lengkuas, Baisan (rica), Gisik Kesik (Kulit kayu), dll. Seluruh sumber daya pangan, papan dan obat-obatan tersebut, selain digunakan untuk kebutuhan subsisten, namun juga untuk tujuan ekonomi.

Hutan disebut sebagai mailin dalam bahasa lokal. Hutan bagi masyarakat adat Moi Kelim adalah sejarah kehidupan. Setiap kelompok marga memiliki klaim atas wilayah hutan tertentu sehingga hutan juga menjadi elemen konstruksi identitas mereka. Tidak ada sistem zonasi khusus atas wilayah hutan, kecuali kategori berdasarkan peruntukannya maupun nilai budaya setempat. Pemanfaatan hutan mengutamakan keberlanjutan dengan hanya memperbolehkan pemanfaatan untuk kepentingan subsisten misalnya kayu untuk memasak dan mendirikan rumah, di luar itu untuk kepentingan komersial misalnya, sangat dilarang. Aturan seperti ini disebut Egeg atau woti, yaitu melarang pemanfaatan hutan yang tidak pada tempatnya. Masyarakat sangat menghormati aturan ini, karena denda yang sangat tinggi, yaitu kain timor, seharga minimal 2,5 juta rupiah, dan sanksi sosial lainnya.

Model pemanfaatan berkelanjutan dan konservasif juga dilakukan masyarakat adat Moi Kelim di Malaumkarta melalui pengelolaan sumber daya pesisir seperti ikan, yang disebut sebagai sasi. Sasi merupakan instrumen pembatasan eksploitasi (limited entry) pada waktu tertentu untuk beberapa sumber daya ikan seperti udang lobster, Tripang dan Lola (sejenis kerang). Pada pengaturan sasi. Penangkapan ketiga jenis ikan tersebut dilarang selama 1 tahun, dan hanya dibuka setiap bulan Mei pada tahun berikutnya. Kegiatan eksploitasi hanya boleh dilakukan selama 1 bulan secara bersama-sama, dan hasilnya dijual untuk dijadikan dana kampung dan gereja. Pada 2 minggu berikutnya di Bulan Juni masyarakat diperbolehkan menangkap ikan untuk kebutuhan pribadi dan ekonomi keluarga. Alat tangkap yang diperbolehkan adalah alat tangkap yang ramah lingkungan seperti pancing, jerat dan tombak. Proses penangkapan dilakukan dengan menyelam. Hukum adat diberlakukan pada pelanggar sasi, berdasarkan kepercayaan masyarakat adat, yaitu pelanggar akan sakit atau meninggal, dan ada biaya adat pembayaran kain timor seharga lebih dari 2 juta rupiah.

Hasil survey dan wawancara dengan responden perikanan non sasi, sebanyak 15 orang dari 20 orang nelayan penuh yang ada menunjukkan bahwa nelayan di Malaumkarta hampir seluruhnya laki-laki, dan $60 \%$ sudah menikah. Alat tangkap yang digunakan adalah pancing, jerat dan tombak. Rata-rata alat tangkap yang dimiliki antara 1 sampai dengan 6 buah. Mereka menangkap ikan dengan cara menyelam. Hampir seluruh nelayan menggunakan hasil tangkapannya untuk kebutuhan pangan sendiri, sisanya antara 10-30 \% mereka gunakan untuk dijual. Hanya satu responden yang menjual $50 \%$ dari hasil tangkapannya. Jenis ikan yang ditangkap diantaranya, Bobara, Kakap merah, Kakap hitam, Kerapu, Tenggiri, Samandar, Bolobo, Sako, dan lain-lain. Masyarakat hanya mengambil ikan seperlunya dan cenderung tidak mengkomersialisasi perikanan tangkap.

Model pemanfaatan sumber daya teresterial lainnya adalah dari jasa lingkungan, dalam hal ini adalah pariwisata. Potensi pariwisata yang ada di wilayah ini mencakup hutan alami, gua kelelawar, berbagai jenis keaneka regaman hayati darat, seperti burung Cenderawasih, kelelawar, burung Pekakak, dan berbagai jenis burung lainnya. Kegiatan ini hanya dilakukan oleh satu operator, dengan dibantu pemandu dari masyarakat setempat. Kegiatan ini sifatnya masih sangat tradisional, penginapan yang didirikan juga masih dalam batas keberlanjutan.

Masyarakat adat Malaumkarta dikenal juga memiliki kekayaan budaya dalam bentuk tari-tarian tradisional, cerita-cerita kuno yang menjadi ciri khas masyarakat adat di wilayah 
ini. Beberapa jenis budaya tarian yang ada di Malaumkarta diantaranya adalah tari yosim (dansa dengan musik dari suara mulut), tari aklen. Selain itu masyarakat disini juga memiliki budaya memanfaatkan kulit kayu untuk membuat noken, egeg (tempat-tempat yang dilarang oleh adat untuk dikunjungi), Kaoof (tempat keramat). Sementara pengetahuan tradisional yang mereka miliki diantaranya adalah pemanfaatan daun gatal (semelas), Tali Kuning (kilofum), sentolas (daun untuk anak yang belajar jalan), dan lain-lain.

\section{PENUTUP}

Masyarakat adat pesisir di Malaumkarta memberikan gambaran bagaimana mansyarakat adat pesisir berperan dan aktif dalam pengelolaan dan pemanfaatan sumber daya pesisir yang berkelanjutan. Konsep subsisten, dan juga pola pemanfaatan instrumen sosial dalam penegakan aturan menjadikan skema ini berjalan secara turun temurun dan berhasil mempertahankan ekosistem pesisir yang ada secara berkelanjutan. Masyarakat adat secara konsisten mempertahankan wilayah, dan keberadaan mereka dan secara berkelanjutan dengan pola-pola pengetahuan dan kearifan tradisional.

Namun demikian, tekanan ke depan yang akan dihadapi sangatlah berat, mengingat dorongan untuk pengembangan wilayah dan pembangunan di wilayah Sorong dan Papua Barat memiliki permintaan yang sangat tinggi. Hal ini terlihat dari laju konversi lahan yang tinggi di wilayah ini, apalagi wilayah masyarakat adat Moi Kelim di Malaumkarta memiliki potensi keindahan alam dan juga sumber daya alam yang sangat besar. Dengan demikian, perlu dipikirkan ke depan pola-pola pengembangan yang tidak akan merusak sumber daya alam dan lingkungan serta memarginalkan masyarakat adat yang telah berkontribusi dalam pengelolaan sumber daya alam dan lingkungan selama ini.

Selain itu, pamahaman para pengambil keputusan mengenai pola pemanfaatan dan pengelolaan masyarakat adat pesisir dan juga nilai lanskap masyarakat adat pesisir menjadi informasi yang penting untuk pengembangan wilayah ini ke depan. Hal yang belum banyak dilakukan adalah menghitung nilai ekonomi total lanskap masyarakat adat pesisir, yang akan dapat memberikan gambaran bagaimana trade off scenario kebijakan pengembangan wilayah yang direncanakan akan memberikan nilai ekonomi yang paling tinggi. Nilai ekonomi masyarakat adat pesisir tidak saja berasal dari kegiatan pemanfaatan, namun juga nonpemanfaatan.

Penelitian ini mendorong rekomendasi strategi untuk upaya pengelolaan peningkatan nilai manfaat dan non manfaat dengan cara mempertahankan pola ekonomi non ekstraktif (subsisten) masyarakat adat, meningkatkan pola ekonomi pada sistem budidaya baik pertanian maupun perikanan yang berkelanjutan. Selain itu, mendorong masyarakat untuk mempertahankan pola pengelolaan berbasis kearifan tradisional seperti Sasi, namun meningkatkan pengetahuan masyarakat melalui pola EAFM (Ecosystem Approach to Fisheries Management). Dalam hal ini, masyarakat diberikan pengetahuan pengelolaan perikanan tangkap berbasis ekosistem, dan mendorong pencatatan data statistik berbasis masyarakat baik untuk pemanfaatan sumber daya maupun untuk pengelolaannya. Masyarakat adat juga perlu diperkenalkan pada pengelolaan nilai tambah komoditas produksi mereka dengan pelatihan pengolahan dan industri hasil pertanian, perkebunan, perikanan dan hasil hutan non kayu.

\section{UCAPAN TERIMA KASIH}

Penulis mengucapkan terima kasih kepada Aliansi Masyarakat Adat Nusantara (AMAN) yang telah mendanai penelitian ini melalui research grant dari CLUE.

\section{DAFTAR PUSTAKA}

Cobo, J.R.M. 1983. Final report (last part) submitted by the Special Rapporteur, Mr. José R. Martínez Cobo. New York: United Nations; 1983. Report No.: E/CN.4/Sub.2/21/Add.8.

Cheung, W.W.L, R. Watson, and D. Pauly. 2013. Signature of ocean warming in global fisheries catch. Nature 497: 365-368. Doi: 10.1038/ nature12156 [PubMed]. 
Cisneros-Montemayor, A.M, D. Pauly, L.V. Weatherdon, and Y. Ota (2016) A Global Estimate of Seafood Consumption by Coastal Indigenous Peoples. PLoS ONE 11(12): e0166681. https://doi.org/10.1371/ journal.pone.0166681. (Tanggal Akses: 13 Mei 2018)

Crossland, C.J., H.H. Kremer, H.J. Lindeboom, J.I.M. Crossland, M.D.A. Le Tissier (Eds). 2005. Coastal Fluxes in the Anthropocene. The Land-Ocean Interactions in the Coastal Zone Project of the International GeosphereBiosphere Programme. Springer, Berlin and Heidelberg.

Davey, L and A. Day. 2008. Reflections on methodology and process: a nonIndigenous perspective, in Day $A$, Nakata $M$ and Howells $\mathrm{K}$ (eds), Anger and Indigenous men: understanding and responding to violent behaviour. Sydney: Federation Press: 151-157.

Davy, C., S. Harfield, A. McAthur, Z. Munn, and A. Brown. 2016. Access to Primary Care Services for Indigenous Peoples:AFramework Synthesis. International Journal for Equity in HealthThe official journal of the International Society for Equity in Health 15:163.

Henry, J., T. Dunbar, A. Arnott, M. Scrimgeour, L. Murakami-Gold. 2004. Indigenous research reform agenda: a review of the literature. Links Monograph Series: 5. Darwin: Cooperative Research Centre for Aboriginal and Tropical Health. http:// www.lowitja.org.au/sites/default/ files/ docs/IRRA5LinksMonographs.pdf. (Diakses tanggal: 30 April 2018)

International Labour Organization (ILO). 2018. Who are the indigenous and tribal people? http:// www.ilo.org/global/topics/indigenous-tribal/ WCMS_503321/lang--en/index.htm. (Diakses tanggal: 1 Juni 2018)

Jackson JBC. 2001. Historical Overfishing and the Recent Collapse of Coastal Ecosystems. Science. 293: 629-637. doi: 10.1126/science.1059199 [PubMed].

Kidman, J. 2007. Engaging with Māori communities: An exploration of some tensions in the mediation of social sciences research. Tihei Oreore Monograph Series. Auckland: Ngā Pae o te Māramatanga, University of Auckland. http://www.maramatanga. ac.nz/sites/default/ files/TO\%20 Kidman.pdf. (Diakses tanggal: 12 Juni 2018)
Morley, S. 2015. What works in effective Indigenous community-managed programs and organisations. Child Family Community Australia. Paper No. 32 2015. 14 Pp

McNiven I. Saltwater People: spiritscapes, maritime rituals and the archaeology of Australian indigenous seascapes. World Archaeol. 2004. 35:329-349. Doi: 10.1080/0043824042000 185757

Nicholls R.J., S. Hanson, C. Herweijer, N. Patmore, S. Hallegatt, J. Corfee-Morlot, J. Chateau, R. Muir-Wood. 2007. Ranking port cities with high exposure and vulnerability to climate extremes-exposure estimates. OECD environmental working paper no. 1, Organisation for Economic Co-operation and Development (OECD), Paris.

Pauly D. 1998. Fishing Down Marine Food Webs. Science 279: 860-863. doi: 10.1126/ science.279.5352.860[PubMed]

Sherwood, J. 2010. Do no harm: decolonising Aboriginal health research. PhD thesis, University of New South Wales.

Welker, G, 2016. Indigenous peoples Literature. http:// www.indigenouspeople.net/. (Diakses tanggal: 12 Juni 2018)

Wittman, H. 2011. Food Sovereignty: A New Rights Framework for Food and Nature? Environ Soc Adv Res. 2011;2: 87-105. doi: 10.3167/ ares.2011.020106.

Zeller, D., S. Booth, E. Pakhomov, W. Swartz, and D. Pauly. Arctic fisheries catches in Russia, USA, and Canada: baselines for neglected ecosystems. Polar Biol. 2011;34: 955-973. doi: 10.1007/s00300-010-0952-3. 